\title{
2 Late Variscan deformation in the Iberian Peninsula; a late feature in the Laurentia-Gondwana dextral collision
}

4 R. Dias $^{1,2,3} \cdot$ N. Moreira ${ }^{1,3}(1) \cdot A$. Ribeiro $^{4} \cdot$ C. Basile $^{3}$

5 Received: 5 February 2016 / Accepted: 5 October 2016

6 C) Springer-Verlag Berlin Heidelberg 2016

\begin{abstract}
The Late Variscan deformation event in Iberia is characterized by an intraplate deformation regime induced by the dextral oblique collision between Laurentia and Gondwana. This episode in Iberia is characterized by NNE-SSW brittle to brittle-ductile strike-slip faults, which are considered by the classic works as sinistral strikeslip faults. However, the absence of Mesozoic formations constraining the age of this sinistral kinematics led some authors to consider it as the result of Alpine reworking. Structural studies in Almograve and Ponta Ruiva sectors (SW Portugal) show that NNE-SSW faults have a sinistral kinematics and are occasionally associated with $\mathrm{E}-\mathrm{W}$ dextral shears. Moreover, this kinematics is related to the late deformation episodes of Variscan orogeny. In Almograve sector, the Late Variscan structures are characterized by NNE-SSW sinistral kink bands, spatially associated with E-W dextral faults. These structures are contemporaneous and affect the previously deformed Carboniferous units. The Ponta Ruiva Sector constrains the age of deformation
\end{abstract}

N. Moreira

nmoreira@estremoz.cienciaviva.pt

1 Earth Sciences Institute (ICT), Pole of the University of Évora, Rua Romão Ramalho, n ${ }^{\circ}$ 9, 7000-671 Évora, Portugal

2 Dep. Geociências da Escola de Ciências e Tecnologia da Universidade de Évora (ECTUE), Largo dos Colegiais, 2-Apartado 94, 7002-554 Évora, Portugal

3 Laboratório de Investigação de Rochas Industriais e Ornamentais da ECTUE, Convento das Maltezas, 7100-513 Estremoz, Portugal

4 Centro de Geologia da Universidade de Lisboa (UL), Dep. Geologia da Faculdade de Ciências da UL, Museu Nacional de História Natural e da Ciência (UL), Edifício C6, Piso 4, Campo Grande, 1749-016 Lisbon, Portugal

because the E-W dextral shears affect the Late Carboniferous (late Moscovian) units, but not the overlying Triassic series. The new data show that the NNE-SSW and the $\mathrm{E}-\mathrm{W}$ faults are dynamically associated and result from the Late Variscan deformation episode. The NNE-SSW sinistral faults could be considered as second-order domino structures related to first-order E-W dextral shears, linked to Laurentia-Gondwana collision during Late Carboniferous-Permian times.

Keywords Iberia Variscan orogeny $\cdot$ Late Variscan deformation $\cdot$ South Portuguese Zone $\cdot$ Kink bands

26

\section{Introduction}

A complex network of major shear zones was developed during the last stages of intracontinental deformation of the Variscan orogeny. This Late Variscan deformation episode was considered the result of internal deformation along first-order E-W dextral shear zones (Arthaud and Matte 1975, 1977). Such kinematics is often considered a pervasive feature of most of the Variscan orogenic evolution (Ribeiro et al. 1995; Shelley and Bossière 2000, 2002; Ribeiro 2002; Ribeiro et al. 2007; Martínez Catalán 2011; Nance et al. 2012; Dias et al. 2016). In the Iberian Massif, this Late Variscan deformation gave rise to some of the most important observed basement faults (Ribeiro 1974; Iglesias and Ribeiro 1981), like the NNE-SSW Vilariça and Régua-Chaves-Verin faults in NW Iberia (Ribeiro et al. 1990; Marques et al. 2002; Moreira et al. 2010; Dias et al. 2013). Although several works focus on this major event, there are still some doubts concerning the kinematics and the timing of the deformation. Such controversy mainly results from the strong reworking of the Late Variscan

\begin{tabular}{|l|ll|}
\hline Journal : Large 531 & Dispatch : 24-10-2016 & Pages : 19 \\
Article No : 1409 & $\square$ LE & $\square$ TYPESET \\
MS Code : IJES-D-16-00050 & $\square \quad C P$ & $\square$ DISK \\
\hline
\end{tabular}

